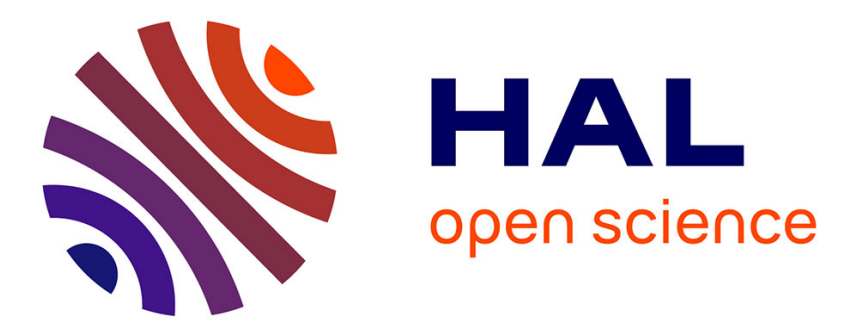

\title{
Protonation and oxidation chemistry of a pentaethylcyclopentadienyl-containing molybdenum(IV) trihydride complex
}

Dolores Morales, Rinaldo Poli, Jacques Andrieu

\section{To cite this version:}

Dolores Morales, Rinaldo Poli, Jacques Andrieu. Protonation and oxidation chemistry of a pentaethylcyclopentadienyl-containing molybdenum(IV) trihydride complex. Inorganica Chimica Acta, 2000, 300-302, pp.709-720. 10.1016/S0020-1693(99)00584-8 . hal-03295988

\section{HAL Id: hal-03295988 \\ https://hal.science/hal-03295988}

Submitted on 28 Jul 2021

HAL is a multi-disciplinary open access archive for the deposit and dissemination of scientific research documents, whether they are published or not. The documents may come from teaching and research institutions in France or abroad, or from public or private research centers.
L'archive ouverte pluridisciplinaire $\mathbf{H A L}$, est destinée au dépôt et à la diffusion de documents scientifiques de niveau recherche, publiés ou non, émanant des établissements d'enseignement et de recherche français ou étrangers, des laboratoires publics ou privés. 


\title{
Protonation and oxidation chemistry of a pentaethylcyclopentadienyl-containing molybdenum(IV) trihydride complex
}

\author{
Dolores Morales, Rinaldo Poli*, Jacques Andrieu \\ Laboratoire de Synthèse et d'Electrosynthèse Organométalliques, Université de Bourgogne, 6 boulevard Gabriel, 21000 Dijon, France
}

Received 7 October 1999; accepted 25 November 1999

\begin{abstract}
Compound $\mathrm{Cp}^{\mathrm{Et}} \mathrm{MoCl}_{4}\left(\mathrm{Cp}^{\mathrm{Et}}=\eta^{5}-\mathrm{C}_{5} \mathrm{Et} 5\right)(\mathbf{1})$ can be transformed into $\mathrm{Cp}^{\mathrm{Et}} \mathrm{MoH}_{3}(\mathrm{dppe})(\mathbf{2})$ and $\mathrm{Cp}^{\mathrm{Et}} \mathrm{MoD}_{3}(\mathrm{dppe})\left(\mathbf{2}-\boldsymbol{d}^{\mathbf{3}}\right)$ [dppe $=1,2-$ (diphenylphosphino)ethane] by reaction with $\mathrm{LiAlX}_{4}(\mathrm{X}=\mathrm{H}$ and $\mathrm{D}$, respectively). The protonation and oxidation studies of these two compounds, in comparison with previously reported studies on $\left(\mathrm{C}_{5} \mathrm{Me}_{5}\right)$ analogs, show important differences that may be attributed to a kinetic stabilization of the products, which is steric in nature. Protonation of $\mathbf{2}$ with $\mathrm{HBF}_{4}$ in acetonitrile affords $\left[\mathrm{Cp}^{\mathrm{Et}} \mathrm{MoH}_{4}(\mathrm{dppe})\right]^{+}(\mathbf{3})$, which only slowly decomposes to $\left[\mathrm{Cp}^{\mathrm{Et}} \mathrm{MoH}_{2}(\mathrm{MeCN})(\mathrm{dppe})\right]^{+}(\mathbf{4})$. Further protona-tion of the latter affords the monohydride species $\left[\mathrm{Cp} * \mathrm{MoH}(\mathrm{dppe})(\mathrm{MeCN})_{2}\right]^{2+}$ in three different forms, 5-7. Direct protonationof 2 with 2 equiv. of $\mathrm{HBF}_{4}$ shows the formation of all of the above compounds, plus a new compound, $\left[\mathrm{Cp}^{\mathrm{Et}} \mathrm{MoH}_{3}(\mathrm{dppe})(\mathrm{MeCN})\right]^{2+}(\mathbf{8})$, to which a classical structure is assigned. The protonation of $\mathbf{2}-\boldsymbol{d}^{\mathbf{3}}$ indicates reversibility for the proton transfer processes. The oxidation of $\mathbf{2}$ in MeCN affords [2]'+, which decomposes slowly in $\mathrm{MeCN}$ to afford a mixture of $\mathbf{4}$ and $\mathbf{5}$ as major products. No compound $\mathbf{8}$, on the other hand, is obtained by oxidation of $\mathbf{2}$, neither with 1 nor with 2 equiv.of oxidizing agent. Mechanistic schemes that rationalize all these observations are proposed.
\end{abstract}

Keywords: Protonation; Oxidation; Molybdenum(IV) complexes; Trihydride complexes; Pentaethylcyclopentadienyl complexes

\section{Introduction}

Polyhydride complexes have long attracted considerable attention for a variety of reasons, both practical and fundamental, such as hydrogen storage, hydrogenation catalysis, molecular dynamics, chemical bonding, and so forth [1-5]. Our own interest is the kinetic stabilization of paramagnetic complexes and their eventual transformation into highly unsaturated, reactive intermediates. The half-sandwich derivatives of type $\left(\eta^{5}-\right.$ $\left.\mathrm{C}_{5} \mathrm{R}_{5}\right) \mathrm{MH}_{3} \mathrm{~L}_{2}$ for the heavy Group 6 metals (Mo and W) were initially developed with unsubstituted or singly substituted cyclopentadienyl ligands by the Green group [6-8]. We have more recently reportedthat the use of the sterically encumbering $\mathrm{Cp}^{*}$ ligand

* Corresponding author. Tel.: +33-38-039 6881; fax: +33-38-039 6098.

E-mail address: poli@u-bourgogne.fr (R. Poli) for Mo systems provides kinetic stabilization to reactive derivatives, such as the protonation and the one-electron oxidation products. Thus, protonation of $\mathrm{Cp}^{*} \mathrm{MoH}_{3}$ (dppe) affords complex $\left[\mathrm{Cp} * \mathrm{MoH}_{4}(\mathrm{dppe})\right]^{+}$, which is stable in THF and has a short lifetime in $\mathrm{MeCN}$ before decomposing to $\left[\mathrm{Cp} * \mathrm{MoH}_{2}(\mathrm{MeCN})(\mathrm{dppe})\right]^{+}$with loss of $\mathrm{H}_{2}[9,10]$. Less substituted $\mathrm{Cp}$ derivatives, on the other hand, do now allow the observation of the tetrahydrido intermediate in $\mathrm{MeCN}$. In addition, oxidation of the same compound affords $\left[\mathrm{Cp}^{*} \mathrm{MoH}_{3} \text { (dppe) }\right]^{+}$, which slowly decomposes in THF or $\mathrm{CH}_{2} \mathrm{Cl}_{2}$ by $\mathrm{H}_{2}$ reductive elimination and in $\mathrm{MeCN}$ by disproportionation or proton transfer, depending on conditions [11,12]. Again, similar derivatives with less sterically encumbering cyclopentadienyl rings do not lead to observable one-electron oxidation products. We have therefore resolved to pursue our search for sterically more encumbering systems in order to control the rate 
of decomposition of the above-mentioned reactive products and possibly trap other previously unobserved intermediates. We report here our protonation and oxidation studies on the pentaethylcyclopentadienyl complex $\mathrm{Cp}^{\mathrm{Et}} \mathrm{MoH}_{3}$ (dppe) $\left(\mathrm{Cp}^{\mathrm{Et}}=\mathrm{C}_{5} \mathrm{Et}_{5}\right)$ and on the corresponding deuteriated analog, $\mathrm{Cp}^{\mathrm{Et}} \mathrm{MoD}_{3}(\mathrm{dppe})$, which have allowed us to obtain new information on the protonation mechanism and to identify a previously undetected product of double protonation, $\left[\mathrm{Cp}^{\mathrm{Et}} \mathrm{MoH}_{3}(\mathrm{MeCN})(\mathrm{dppe})\right]^{2+}$.

\section{Experimental}

\subsection{General procedures}

All the manipulations were carried out under an atmosphere of argon by the use of Schlenk line or glovebox techniques. Solvents were dried and distilled by conventional methods (MeOH from $\mathrm{Mg}$, THF from $\mathrm{Na} / \mathrm{K} /$ benzophenone, $\mathrm{Et}_{2} \mathrm{O}$, toluene and pentane from $\mathrm{Na}$ - benzophenone, $\mathrm{MeCN}$ from $\mathrm{CaH}_{2}$ and $\mathrm{CH}_{2} \mathrm{Cl}_{2}$ from $\mathrm{P}_{2} \mathrm{O}_{5}$ ) prior to use. All deuteriated solvents were degassed by three freeze-pump-thaw cycles prior to use. All except $\mathrm{MeOD}, \mathrm{CF}_{3} \mathrm{COOD}$ and $\mathrm{D}_{2} \mathrm{O}$ were previously dried over molecular sieves. $\mathrm{HBF}_{4} \cdot \mathrm{OEt}_{2}$ was used as received, without further purification. ${ }^{1} \mathrm{H}$ and ${ }^{31} \mathrm{P}\left\{{ }^{1} \mathrm{H}\right\}$ NMR measurements were carried out on a Bruker AC-200 spectrometer. The peak positions are reported with positive shifts downfield of $\mathrm{SiMe}_{4}$ as calculated from the residual solvents peaks $\left({ }^{1} \mathrm{H}\right)$ or downfield of external $85 \%$ $\mathrm{H}_{3} \mathrm{PO}_{4}\left({ }^{31} \mathrm{P}\right)$. EPR measure- ments were carried out at the $\mathrm{X}$-band microwave frequency on a Bruker ESP300 spectrometer. The spectrometer frequency was calibrated with diphenylpicrylhydrazyl $(g=2.0037)$. Cyclic voltammograms were carried out at $20^{\circ} \mathrm{C}$ in a three-electrode cell with an EG\&G 283 potentiostat connected to a Macintosh computer via a MacLab analog/digital converter. The working electrode was a $3 \mathrm{~mm}$ diameter carbon disk or a $0.5 \mathrm{~mm}$ diameter platinum disk. $\mathrm{Bu}_{4} \mathrm{NPF}_{6}(0.1 \mathrm{M})$ was used as supporting electrolyte. All potentials are reported relative to the ferrocene standard, which was added to each solution and measured at the end of the experiments. The elemental analyses were carried out by the analytical service of the Laboratoire de Synthèse et d'Electrosynthèse Organométalliques with a Fisons Instruments EA1108 analyzer. $\mathrm{PhICl}_{2}[13]$ and $\left[\mathrm{Cp}_{2} \mathrm{Fe}\right]\left[\mathrm{BF}_{4}\right]$ [14] were prepared according to the literature procedures. $\left[\mathrm{Cp}_{2} \mathrm{Fe}\right]\left[\mathrm{BAr}{ }_{4}\right]\left(\mathrm{Ar}{ }^{\prime}=3,5-\mathrm{CH}_{3}\left(\mathrm{CF}_{3}\right)_{2}\right)$ was prepared according to the previously reported protocol for the preparation of $\left[\mathrm{Cp}_{2} \mathrm{Fe}\right]\left[\mathrm{BPh}_{4}\right]$ [14] from $\mathrm{Cp}_{2} \mathrm{Fe}$ and $\mathrm{Na}\left[\mathrm{BAr}_{4}{ }_{4}\right][15]$.

\subsection{Synthesis of $\mathrm{Cp}^{E t} \mathrm{MoCl}_{4}$ (1)}

This method is a straightforward adaptation of the previously reported $[16,17]$ synthesis of $\mathrm{Cp} * \mathrm{MoCl}_{4}$. To a solution of $\mathrm{Cp}^{\mathrm{Et}} \mathrm{Mo}(\mathrm{CO})_{3} \mathrm{CH}_{3}(3.02 \mathrm{~g}, 7.54 \mathrm{mmol})$ in $50 \mathrm{ml}$ of $\mathrm{CH}_{2} \mathrm{Cl}_{2}$ was slowly added a suspension of $\mathrm{PhICl}_{2}$ (5.186 g, $18.85 \mathrm{mmol})$ in $50 \mathrm{ml}$ of $\mathrm{CH}_{2} \mathrm{Cl}_{2}$ causing $\mathrm{CO}$ evolution. During the addition the color changed from yellow to red. After stirring for $1 \mathrm{~h}$ at room temperature (r.t.), the solvent was evaporated to approximately $50 \mathrm{ml}$ and pentane $(50 \mathrm{ml})$ was added causing the precipitation of 1 as a red crystalline solid. The product was filtered off, washed with pentane $(5 \times 10 \mathrm{ml})$ and dried in vacuo. Yield: $2.624 \mathrm{~g}, 78 \%$. Anal. Calc. for $\mathrm{C}_{15} \mathrm{H}_{25} \mathrm{Cl}_{4} \mathrm{Mo}$ : C, 40.66; H, 5.69. Found: C, 40.41; H, 5.71\%. EPR $\left(\mathrm{CH}_{2} \mathrm{Cl}_{2}\right): g=1.990$ (s, with Mo satellites, $a_{\mathrm{Mo}}=38.8 \mathrm{G}$ ).

\subsection{Synthesis of $\mathrm{Cp}^{\mathrm{Et}} \mathrm{MoH}_{3}($ dppe) (2)}

This synthesis follows the previously reported protocol for the preparation of $\mathrm{Cp}^{*} \mathrm{MoH}_{3}$ (dppe) [10]. To a solution of $\mathrm{Cp}^{\mathrm{Et}} \mathrm{MoCl}_{4}(2.258 \mathrm{~g}, 5.09 \mathrm{mmol})$ in a mixture of toluene-ether $(60 \mathrm{ml} / 20 \mathrm{ml})$ was added a solution of dppe $(2.03 \mathrm{~g}, 5.09 \mathrm{mmol})$ in $30 \mathrm{ml}$ of toluene, causing a color change from red to brown. $\mathrm{LiAlH}_{4}(5.09 \mathrm{~g}, 49.37$ mmol) was added resulting in gas evolution and a color change to orange within $15 \mathrm{~min}$. The mixture was stirred overnight to give a yellow solution. $\mathrm{MeOH}$ (approximately $12 \mathrm{ml}$ ) was added dropwise with stirring until $\mathrm{H}_{2}$ evolution ceased, causing a darkeningof the solution. The stirring was continued for $1 \mathrm{~h}$ at r.t., followed by evaporation to dryness. The residue was extracted with pentane (approximately $100 \mathrm{ml}$ ) and filtered through Celite. Concentration of the solution to approximately $5 \mathrm{ml}$ yielded $\mathbf{2}$ as a microcrystalline yellow precipitate. The product was filtered off, washed with cold pentane and dried under reduced pressure. Yield: $2.945 \mathrm{~g}, 82 \%$. Anal. Calc. for $\mathrm{C}_{41} \mathrm{H}_{52} \mathrm{MoP}_{2}$ : C, 70.07; H, 7.46. Found: C, 70.24; H, 7.68\%. ${ }^{31} \mathrm{P}\left\{{ }^{1} \mathrm{H}\right\}$ $\operatorname{NMR}\left(\mathrm{C}_{6} \mathrm{D}_{6}, \mathrm{~d}\right): 90.9 .{ }^{1} \mathrm{H}$ NMR $\left(\mathrm{C}_{6} \mathrm{D}_{6}, \mathrm{~d}\right): 7.8-7.0(\mathrm{~m}$, $20 \mathrm{H}$, dppe $\mathrm{Ph}$ ), $2.30\left(\mathrm{q}, J_{\mathrm{HH}}=7.5 \mathrm{~Hz}, 10 \mathrm{H}, \mathrm{Cp}^{\mathrm{Et}} \mathrm{CH}_{2}\right.$ ), $1.95\left(\mathrm{~d}, J_{\mathrm{PH}}=15.1 \mathrm{~Hz}, 4 \mathrm{H}\right.$, dppe $\left.\mathrm{CH}_{2}\right), 1.11\left(\mathrm{t}, J_{\mathrm{HH}}=7.3\right.$ $\left.\mathrm{Hz}, 15 \mathrm{H}, \mathrm{Cp}^{\mathrm{Et}} \mathrm{CH}_{3}\right),-5.42\left(\mathrm{t}, J_{\mathrm{PH}}=48.3 \mathrm{~Hz}, 3 \mathrm{H}, \mathrm{Mo}\right.$ $\mathrm{H})$. Cyclic voltammetric inves- tigations showed a reversible oxidation at $E_{1 / 2}=-0.76 \mathrm{~V}(\mathrm{MeCN})$ or -0.82 $\mathrm{V}\left(\mathrm{CH}_{2} \mathrm{Cl}_{2}\right)$, followed by a second irreversible oxidation with $E_{\mathrm{p}, \mathrm{a}}=+0.66(\mathrm{MeCN})$ or $+0.72\left(\mathrm{CH}_{2} \mathrm{Cl}_{2}\right)$.

\subsection{Synthesis of $C p^{E t} M o D_{3}($ dppe $)\left(2-d^{3}\right)$}

This compound was prepared following the same procedure reported previously [10] for $\mathrm{Cp}^{*} \mathrm{MoD}_{3}$ (dppe) and above for compound 2. To a solution of $\mathrm{Cp}^{\mathrm{Et}} \mathrm{MoCl}_{4}$ $(0.366 \mathrm{~g}, 0.82 \mathrm{mmol})$ in a mixture of toluene-ether 
$(30 \mathrm{ml} / 5 \mathrm{ml})$ was added dppe $(0.329 \mathrm{~g}, 0.82 \mathrm{mmol})$ and $\mathrm{LiAlD}_{4}(0.340 \mathrm{~g}, 7.95 \mathrm{mmol})$ causing gas evolution. The mixture was stirred overnight resulting in a yellow solution. MeOD (approximately $3 \mathrm{ml}$ ) was added dropwise causing $\mathrm{D}_{2}$ evolution and a darkening of the solution. The stirring was continued for $1 \mathrm{~h}$ and then the mixture was evaporated to dryness. The residue was extracted with pentane (approximately $50 \mathrm{ml}$ ) and filtered through Celite. Concentration of the solution under vacuum to approximately $2 \mathrm{ml}$ precipitated $\mathbf{2}-\boldsymbol{d}^{\mathbf{3}}$ as a microcrystalline yellow solid, which was washed with $\mathrm{CH}_{3} \mathrm{CN}$ and dried in vacuo. Yield: $0.368 \mathrm{~g}, 64 \%$. ${ }^{31} \mathrm{P}\left\{{ }^{1} \mathrm{H}\right\}$ NMR $\left(\mathrm{C}_{6} \mathrm{D}_{6}, \mathrm{~d}\right): 91.2 .{ }^{1} \mathrm{H}$ NMR $\left(\mathrm{C}_{6} \mathrm{D}_{6}, \delta\right): 7.8-$ $7.0(\mathrm{~m}, 20 \mathrm{H}$, dppe $\mathrm{Ph}), 2.28\left(\mathrm{q}, J_{\mathrm{HH}}=7.5 \mathrm{~Hz}, 10 \mathrm{H}, \mathrm{Cp}^{\mathrm{Et}}\right.$ $\left.\mathrm{CH}_{2}\right), 1.95\left(\mathrm{~d}, J_{\mathrm{PH}}=15.1 \mathrm{~Hz}, 4 \mathrm{H}\right.$, dppe $\left.\mathrm{CH}_{2}\right), 1.11(\mathrm{t}$, $\left.J_{\mathrm{HH}}=7.3 \mathrm{~Hz}, 15 \mathrm{H}, \mathrm{Cp}^{\mathrm{Et}} \mathrm{CH}_{3}\right)$.

\subsection{Synthesis of $\left[\mathrm{Cp}^{E t} \mathrm{MoH}_{4}(\mathrm{dppe})\right]\left[\mathrm{BF}_{4}\right]$ (3)}

To a solution of $\mathrm{Cp}^{\mathrm{Et}} \mathrm{MoH}_{3}$ (dppe) $(0.071 \mathrm{~g}, 0.10 \mathrm{mmol})$ in $10 \mathrm{ml}$ of $\mathrm{Et}_{2} \mathrm{O}$ at r.t. was added $\mathrm{HBF}_{4} \cdot \mathrm{OEt}_{2}(21 \mathrm{ml}$, $0.15 \mathrm{mmol}$ ). Compound 3 precipitated immediately as a pale brown solid. The product was isolated by filtration, washed with pentane $(3 \times 5 \mathrm{ml})$ and dried in vacuo. Yield: $0.051 \mathrm{~g}, 64 \%$. Anal. Calc. for $\mathrm{C}_{41} \mathrm{H}_{53} \mathrm{MoP}_{2} \mathrm{BF}_{4}$ : C, 62.29; H, 6.76. Found: C, 62.07; H, 6.98\%. ${ }^{31} \mathrm{P}\left\{{ }^{1} \mathrm{H}\right\}$ NMR $\left(\mathrm{C}_{6} \mathrm{D}_{6}, \mathrm{~d}\right): 72.4$ (s). ${ }^{1} \mathrm{H}$ NMR $\left(\mathrm{C}_{6} \mathrm{D}_{6}, \delta\right): 7.73-7.15$ $(\mathrm{m}, 20 \mathrm{H}, \mathrm{Ph}), 2.24\left(\mathrm{~m}, 10 \mathrm{H}, \mathrm{Cp}^{\mathrm{Et}} \mathrm{CH}_{2}\right), 1.75(\mathrm{~m}, 4 \mathrm{H}$, dppe $\left.\mathrm{CH}_{2}\right), 1.05\left(\mathrm{~m}, 15 \mathrm{H}, \mathrm{Cp}^{\mathrm{Et}} \mathrm{CH}_{3}\right),-3.62(\mathrm{t}$, $\left.J_{\mathrm{PH}}=37.8 \mathrm{~Hz}, 4 \mathrm{H}, \mathrm{M} \mathrm{H}\right)$.

\subsection{Synthesis of $\left[\mathrm{Cp}^{\mathrm{Et}} \mathrm{MoH}_{2}(\mathrm{dppe})\left(\mathrm{CH}_{3} \mathrm{CN}\right)\right]\left[\mathrm{BF}_{4}\right](\mathbf{4})$}

Compound 3 (0.020 g, $0.025 \mathrm{mmol})$ was dissolved in $\mathrm{CH}_{3} \mathrm{CN}(2 \mathrm{ml})$ and the solution was stirred for $2 \mathrm{~h}$,filtered through Celite and concentrated under reduced pressure to approximately $0.5 \mathrm{ml}$. Diethyl ether $(5 \mathrm{ml})$ was added and the solution was cooled to $-20^{\circ} \mathrm{C}$ for $12 \mathrm{~h}$, causing the precipitation of $\mathbf{4}$ as a microcrystalline brown solid. The product was isolated by filtration, washed with pentane and dried in vacuo. Yield: $0.015 \mathrm{~g}, 72 \%$. Anal. Calc. for $\mathrm{C}_{43} \mathrm{H}_{54} \mathrm{MoNP}_{2} \mathrm{BF}_{4}: \mathrm{C}, 62.26 ; \mathrm{H}, 6.56 ; \mathrm{N}$, 1.69. Found: C, 62.36; H, 6.60; N, $1.79 \% .{ }^{31} \mathrm{P}\left\{{ }^{1} \mathrm{H}\right\}$ NMR $\left(\mathrm{CD}_{3} \mathrm{CN}, \delta\right): 73.5$ (s). ${ }^{1} \mathrm{H}$ NMR $\left(\mathrm{CD}_{3} \mathrm{CN}, \delta\right): 7.64$ $-7.53(\mathrm{~m}, 20 \mathrm{H}, \mathrm{Ph}), 2.72-2.6\left(\mathrm{~m}, 10 \mathrm{H}, \mathrm{Cp}^{\mathrm{Et}} \mathrm{CH}_{2}\right), 2.22$ $-2.08\left(\mathrm{~m}, 4 \mathrm{H}\right.$, dppe $\left.\mathrm{CH}_{2}\right) 1.18-1.10\left(\mathrm{~m}, 15 \mathrm{H}, \mathrm{Cp}^{\mathrm{Et}}\right.$ $\left.\mathrm{CH}_{3}\right),-5.47\left(\mathrm{t}, J_{\mathrm{P}^{\prime} \mathrm{H}}=54.0 \mathrm{~Hz}, 2 \mathrm{H}, \mathrm{M} \mathrm{H}\right)$. Cyclic voltammetric investigations in $\mathrm{MeCN}$ showed a reversible oxidation at $E_{1 / 2}=-0.06 \mathrm{~V}$.

\subsection{Synthesis of $\left[\mathrm{Cp}^{\mathrm{Et}} \mathrm{MoH}(\mathrm{dppe})\left(\mathrm{CH}_{3} \mathrm{CN}\right)_{2}\right]\left[\mathrm{BF}_{4}\right]_{2}$}

To a suspension of $\mathrm{Cp}^{\mathrm{Et}} \mathrm{MoH}_{3}$ (dppe) (0.054 g, 0.076 mmol) in $3 \mathrm{ml}$ of $\mathrm{CH}_{3} \mathrm{CN}$ was added $\mathrm{HBF}_{4} \cdot \mathrm{OEt}_{2}(21 \mathrm{ml}$, $0.126 \mathrm{mmol})$ at r.t. The resulting brown solution was stirred for $3 \mathrm{~h}$, resulting in a color change to red. The solution was filtered through Celite and evaporated to dryness. The residue was washed with toluene and redissolved in $\mathrm{CH}_{3} \mathrm{CN}(1 \mathrm{ml})$. Slow diffusion of $\mathrm{Et}_{2} \mathrm{O}(5$ $\mathrm{ml}$ ) into this solution at $-20^{\circ} \mathrm{C}$ yielded red crystals after 12 h. Yield: $0.018 \mathrm{~g}, 25 \%$. Anal. Calc. for $\mathrm{C}_{45} \mathrm{H}_{56} \mathrm{MoN}_{2} \mathrm{P}_{2} \mathrm{~B}_{2} \mathrm{~F}_{8}: \mathrm{C}, 56.51 ; \mathrm{H}, 5.90 ; \mathrm{N}, 2.93$. Found: $\mathrm{C}, 56.83 ; \mathrm{H}, 5.84 ; \mathrm{N}, 2.80 \% .{ }^{31} \mathrm{P}\left\{{ }^{1} \mathrm{H}\right\}$ NMR $\left(\mathrm{CD}_{3} \mathrm{CN}\right.$, $\delta): 72.15\left(\mathrm{~d}, J_{\mathrm{PP}}=24.2 \mathrm{~Hz}\right), 44.52\left(\mathrm{~d}, J_{\mathrm{PP}}=24.4 \mathrm{~Hz}\right)$. ${ }^{1} \mathrm{H}$ NMR $\left(\mathrm{CD}_{3} \mathrm{CN}, \delta\right): 7.9-7.10(\mathrm{~m}, 20 \mathrm{H}, \mathrm{Ph}), 2.20$ $2.6\left(\mathrm{~m}, 14 \mathrm{H}, \mathrm{Cp}^{\mathrm{Et}} \mathrm{CH}_{2}\right.$, dppe $\left.\mathrm{CH}_{2}\right), 1.6\left(\mathrm{~s}, 6 \mathrm{H}, \mathrm{CH}_{3} \mathrm{CN}\right)$, $1.38-1.31\left(\mathrm{~m}, 15 \mathrm{H}, \mathrm{Cp}^{\mathrm{Et}} \mathrm{CH}_{3}\right),-4.03\left(\mathrm{dd}, J_{\mathrm{P} \mathrm{H}}=11.0 \mathrm{~Hz}\right.$, $\left.J_{\mathrm{P}_{i} \mathrm{H}}=84.6 \mathrm{~Hz}, 1 \mathrm{H}, \mathrm{M} \mathrm{H}\right)$.

\subsection{Protonation of compound 2 in acetonitrile}

\subsubsection{With 1 equiv. of $\mathrm{HBF}_{4} \cdot \mathrm{OEt}_{2}$}

To a suspension of $\mathrm{Cp}^{\mathrm{Et}} \mathrm{MoH}_{3}$ (dppe) (0.078 g, 0.011 mmol) in $0.5 \mathrm{ml}$ of $\mathrm{CD}_{3} \mathrm{CN}$ at r.t. was added $\mathrm{HBF}_{4} \cdot \mathrm{OEt}_{2}$ $(1.5 \mathrm{ml}, 0.011 \mathrm{mmol})$. A brown solution wasimmediately obtained. Monitoring this solution by ${ }^{1} \mathrm{H}$ NMR spectroscopy showed the presence of only two complexes, the hydride species $\mathbf{3}$ and $\mathbf{4}$, and the slow conversion of the former into the latter (see Results and Discussion, Sections 3 and 4).

\subsubsection{With 2 equiv. of $\mathrm{HBF}_{4} \cdot \mathrm{OEt}_{2}$}

Various experiments analogous to that described in the previous section were carried out by using com- pounds $\mathrm{Cp}^{\mathrm{Et}} \mathrm{MoH}_{3}$ (dppe) and $\mathrm{HBF}_{4} \cdot \mathrm{OEt}_{2}$ in a $1: 2$ ratio in $\mathrm{CD}_{3} \mathrm{CN}$. The reactions were monitored by ${ }^{1} \mathrm{H},{ }^{31} \mathrm{P}$ NMR spectroscopy, and various other reagents (i.e. $\mathrm{NEt}_{3}$ or $\mathrm{D}_{2} \mathrm{O}$ ) were added at different times after the beginning of the reaction. Compound 5 (NMR proper-ties identical with those reported above) and the new compounds 6,7 and 8 were observed, as detailed in Section 3. Compound 6: ${ }^{31} \mathrm{P}\left\{{ }^{1} \mathrm{H}\right\}$ NMR $\left(\mathrm{CD}_{3} \mathrm{CN}, \delta\right): 69.61$ (br), 62.83 (br). ${ }^{1} \mathrm{H} \quad \mathrm{NMR} \quad\left(\mathrm{CD}_{3} \mathrm{CN}, \quad \delta\right): \quad-2.09 \quad(\mathrm{dd}$, $\left.J_{\mathrm{P}^{\prime} \mathrm{H}}=21.3 \mathrm{~Hz}, J_{\mathrm{P}_{i} \mathrm{H}}=82.3 \mathrm{~Hz}\right)$. Compound $7:{ }^{31} \mathrm{P}\left\{{ }^{1} \mathrm{H}\right\}$ NMR $\left(\mathrm{CD}_{3} \mathrm{CN}, \delta\right): 71.37\left(\mathrm{~d}, J_{P P}=28.2 \mathrm{~Hz}\right), 46.55(\mathrm{~d}$, $\left.J_{P P}=28.2 \mathrm{~Hz}\right) .{ }^{1} \mathrm{H}$ NMR $\left(\mathrm{CD}_{3} \mathrm{CN}, \delta\right):-4.01(\mathrm{dd}, J=9.6$ $\mathrm{Hz}, J=88.2 \mathrm{~Hz})$. Compound 8: ${ }^{31} \mathrm{P}\{\mathrm{H}\} \mathrm{NMR}\left(\mathrm{CD}_{3} \mathrm{CN}\right.$, d): 59.51 (br). ${ }^{1} \mathrm{H}$ NMR $\left(\mathrm{CD}_{3} \mathrm{CN}, \delta\right):-3.11$ (t, $J_{\mathrm{PH}}=31.2 \mathrm{~Hz}$ ).

\subsection{Protonation of compound 4}

\subsubsection{In $T H F$}

To a solution of $\left[\mathrm{Cp}^{\mathrm{Et}} \mathrm{MoH}_{2}(\mathrm{dppe})(\mathrm{MeCN})\right]\left[\mathrm{BF}_{4}\right](0.018 \mathrm{~g}$, $0.022 \mathrm{mmol})$ in $1 \mathrm{ml}$ of THF was added $\mathrm{HBF}_{4} \cdot \mathrm{OEt}_{2}(3 \mathrm{ml}$, $0.022 \mathrm{mmol}$ ) at r.t. The brown solution was stirred for 3 min and the solvent was evaporated in vacuo, followed by redissolution into $\mathrm{CD}_{3} \mathrm{CNfor}{ }^{1} \mathrm{H}$ NMR analysis, which showed the presence of compounds 5, 6 and 7 (see Results, Section 3). 


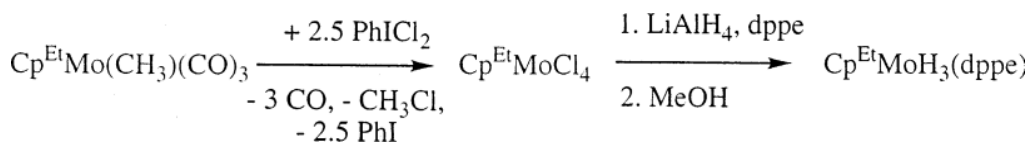

Scheme 1.

\subsubsection{In $\mathrm{CD}_{3} \mathrm{CN}$}

To a solution of $\left[\mathrm{Cp}^{\mathrm{Et}} \mathrm{MoH}_{2}\right.$ (dppe) $\left.(\mathrm{MeCN})\right]\left[\mathrm{BF}_{4}\right]$ (obtained directly by decomposition of $3(0.025 \mathrm{~g}, 0.031$ mmol) in $0.5 \mathrm{ml}$ of $\mathrm{CD}_{3} \mathrm{CN}$ ) was added $\mathrm{HBF}_{4} \cdot \mathrm{OEt}_{2}$ (3 $\mathrm{ml}, 0.022 \mathrm{mmol}$ ), followed by direct monitoring of the reaction by ${ }^{1} \mathrm{H}$ NMR spectroscopy (see Results, Section $3)$.

\subsection{Protonation of compound $2-d^{3}$ in acetonitrile}

\subsubsection{With 1 equiv. of $\mathrm{HBF}_{4} \cdot \mathrm{OEt}_{2}$}

$\mathrm{HBF}_{4} \cdot \mathrm{OEt}_{2}(6.5 \mathrm{ml}, 0.05 \mathrm{mmol})$ was added to a suspension of $\mathrm{Cp}^{\mathrm{Et}} \mathrm{MoD}_{3}$ (dppe) (0.032 g, $\left.0.05 \mathrm{mmol}\right)$ in $0.5 \mathrm{ml}$ of $\mathrm{CD}_{3} \mathrm{CN}$ at r.t. in a 5-mm NMR tube, causing the formation of a brown solution. The evolution of the NMR properties is reported in the Results. After the conversion was complete (approximately $3 \mathrm{~h}$ ), a second equivalent of $\mathrm{HBF}_{4} \cdot \mathrm{OEt}_{2}(6.5 \mathrm{ml}, 0.05 \mathrm{mmol})$ was added to the NMR tube (see Results, Section 3).

\subsubsection{With 2 equi6. of $\mathrm{HBF}_{4} \cdot \mathrm{OEt}_{2}$}

$\mathrm{HBF}_{4} \cdot \mathrm{OEt}_{2}(5.5 \mathrm{ml}, 0.04 \mathrm{mmol})$ was added to a suspension of $\mathrm{Cp}^{\mathrm{Et}} \mathrm{MoD}_{3}$ (dppe) (0.014 g, $\left.0.02 \mathrm{mmol}\right)$ in $0.5 \mathrm{ml}$ of $\mathrm{CD}_{3} \mathrm{CN}$ at r.t., causing the formation of a brown solution. The solution was transfered to an NMR tube and the reaction was monitored by ${ }^{1} \mathrm{H}$ NMR spectroscopy(see Results, Section 3).

\subsection{Chemical oxidation of compound 2 by $\left[\mathrm{Cp}_{2} \mathrm{Fe}\right]\left[\mathrm{BF}_{4}\right]$ in $\mathrm{CD}_{3} \mathrm{CN}$}

\subsubsection{With 1.5 equiv.}

To a suspension of $\mathrm{Cp}^{\mathrm{Et}} \mathrm{MoH}_{3}$ (dppe) $(0.017 \mathrm{~g}, 0.024$ $\mathrm{mmol}$ ) in $0.5 \mathrm{ml}$ of $\mathrm{CD}_{3} \mathrm{CN}$ at $-20^{\circ} \mathrm{C}$ was added $\left[\mathrm{Cp}_{2} \mathrm{Fe}\right]\left[\mathrm{BF}_{4}\right](0.010 \mathrm{~g}, 0.036 \mathrm{mmol})$. An immediate reaction occurred completely dissolving the yellow starting material and yielding a red-brown solution. An EPR spectrum recorded at r.t. exhibited a complex pattern, indicating a mixture of paramagnetic products. These signals disappeared within $1 \mathrm{~h}$ and were replaced by a triplet at $g=1.984, a_{\mathrm{P}}=27.0 \mathrm{G}, a_{\mathrm{Mo}}=47.6 \mathrm{G}$. A ${ }^{1} \mathrm{HNMR}$ spectrum of the solution revealed the presence of compounds 4 and 5 in an approximately 1:1 ratio, plus an unidentified non-hydridic product characterized by a ${ }^{31} \mathrm{P}\left\{{ }^{1} \mathrm{H}\right\}$ NMR signal at $\delta 41 \mathrm{ppm}$.

\subsubsection{With 2 equiv.}

A mixture of $\mathrm{Cp}^{\mathrm{Et}} \mathrm{MoH}_{3}$ (dppe) $(0.024 \mathrm{~g}, 0.034 \mathrm{mmol})$ and $\mathrm{Cp}_{2} \mathrm{FeBF}_{4}(0.019 \mathrm{~g}, 0.068 \mathrm{mmol})$ was dissolved in 0.5 $\mathrm{ml}$ of $\mathrm{CD}_{3} \mathrm{CN}$. An NMR spectrum recorded after approx- imately 5 min showed a mixture of the hydride products $\mathbf{3}$ and $\mathbf{5}$. Compound $\mathbf{3}$ decomposes to $\mathbf{4}$ in approximately $90 \mathrm{~min}$. At this time, the $\mathbf{4 : 5}$ ratio was approximately 6:4. An EPR spectrum of this solution showed a binomial triplet ( $g=1.986, a_{\mathrm{P}}=26.2$ ). The subsequent addition of $\mathrm{NEt}_{3}(5 \mathrm{ml}, 0.034 \mathrm{mmol})$ to this solution did not cause anyvariationof NMRproperties, while the EPRspectrum became silent.

\section{Results}

\subsection{Synthesis and characterization of $\mathrm{Cp}^{E t} \mathrm{MoH}_{3}$ (dppe) and $\mathrm{Cp}^{\mathrm{Et}} \mathrm{MoD}_{3}($ dppe $)$}

The starting compound for our studies, $\mathrm{Cp}^{\mathrm{Et}} \mathrm{MoH}_{3}$ (dppe), has been prepared by a straightforward adaptation of the method which had previously been developed for the analogous $\mathrm{Cp}^{*}$ system (see Scheme 1) [10]. Oxidation of $\mathrm{Cp}^{\mathrm{Et}} \mathrm{MoMe}(\mathrm{CO})_{3}$ with $\mathrm{PhICl}_{2}$ affords $\mathrm{Cp}^{\mathrm{Et}} \mathrm{MoCl}_{4}(\mathbf{1})$ by analogy with the $\mathrm{PCl}_{5}$ oxidation of the corresponding $\mathrm{Cp}^{*}$ system [18]. This compound is more soluble than its $\mathrm{Cp}^{*}$ counterpart but otherwise shows identical chemical, physical and spectroscopic properties. Treatment of 1 with $\mathrm{LiAlH}_{4}$ and dppe affords the trihydride derivative $\mathrm{Cp}^{\mathrm{Et}} \mathrm{MoH}_{3}$ (dppe) (2) in good yields. Use of $\mathrm{LiAlD}_{4}$ according to the same protocol affords $\mathbf{2}-\boldsymbol{d}^{\mathbf{3}}$, which shows no visible contamination by $\mathbf{2}-\boldsymbol{d}^{\boldsymbol{n}}(n<3)$ species by ${ }^{1} \mathrm{H}$ NMR. The NMR properties of compounds $\mathbf{2}$ and $\mathbf{2}-\mathbf{d}^{\mathbf{3}}$, particularly the hydride chemical shift and $J_{\mathrm{HP}}$ coupling constant in the ${ }^{1} \mathrm{H}$ NMR, closely parallel those reported for the $\mathrm{Cp}^{*}$ analogs $[10,12]$.

The electronic properties of $\mathbf{2}$ also parallel those of the $\mathrm{Cp}^{*}$ analog; a reversible one-electron oxidation is observed at $-0.76 \mathrm{~V}$ in $\mathrm{MeCN}$ and $-0.86 \mathrm{~V}$ in $\mathrm{CH}_{2} \mathrm{Cl}_{2}$. Thus, the $\mathrm{Cp}^{\mathrm{Et}}$ ligand has essentially the same electron donating power as the $\mathrm{Cp}^{*}$ ligand for this system. The oxidation product, however, is much less susceptible to decomposition. The oxidation wave of the $\mathrm{Cp}^{*}$ system was reported to be fully reversible only in $\mathrm{CH}_{2} \mathrm{Cl}_{2}$, while reversibility was achieved in $\mathrm{MeCN}$ only at scan rates greater than approximately $100 \mathrm{mV} \mathrm{s}^{-1}$. On the other hand, the oxidation wave of the pentaethylcyclopentadienyl analogis reversible in both solvents at scan rates as low as $10 \mathrm{mV} \mathrm{s}^{-1}$. The EPR spectroscopic properties of the oxidation product, $[2]^{+^{\prime}}$, which was generated in a dry ${ }^{1} \mathrm{THF}$ or dichloromethane solution

\footnotetext{
${ }^{1}$ When water is deliberately added to the solvent or when the latter is incompletely dried, decomposition of $\left[\mathrm{Cp}^{\mathrm{Et}} \mathrm{MoH} \text { (dppe) }\right]^{+}$leads tothe formation of $\mathrm{Cp}^{\mathrm{Et}} \mathrm{Mo}(\mathrm{OH})_{2}$ (dppe), as described elsewhere [28].
} 
by chemical oxidation with $\mathrm{Cp}_{2} \mathrm{Fe}^{+}$, matched closely those of the $\mathrm{Cp}^{*}$ analog $[11,12]$. Although the oxidation of 2 in $\mathrm{MeCN}$ is chemically reversible on the timescale of the cyclic voltammogram, the chemical oxidation leads neverthe- less to decomposition products relatively rapidly. Be- fore examining the nature of these products, we shall present the results of the protonation experiments.

\subsection{Protonation studies}

For practical reasons, all species containing the acetonitrile ligand will be assigned the same numeric label whether they were synthetized in regular $\mathrm{CH}_{3} \mathrm{CN}$ and isolated, or simply observed by NMR by carrying out the reactions in $\mathrm{CD}_{3} \mathrm{CN}$. The deuterium substitution at the hydride positions, on the other hand, will be explicitly shown by a $-d^{n}$ suffix.

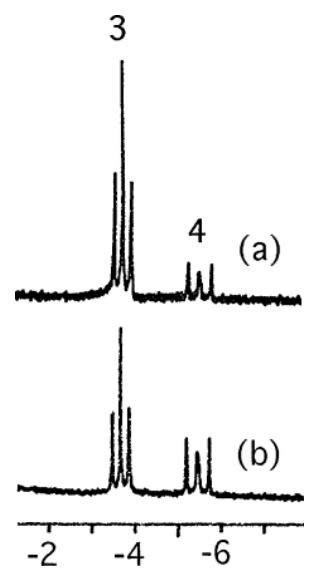

Fig. 1. Representative ${ }^{1} \mathrm{H}$ NMR spectra in the hydride region of the reaction between $\mathrm{Cp}^{\mathrm{Et}} \mathrm{MoH}_{3}$ (dppe) and 1 equiv. of $\mathrm{HBF}_{4}$ in $\mathrm{CD}_{3} \mathrm{CN}$ at r.t. (a) $t=5 \mathrm{~min}$. (b) $t=15 \mathrm{~min}$.

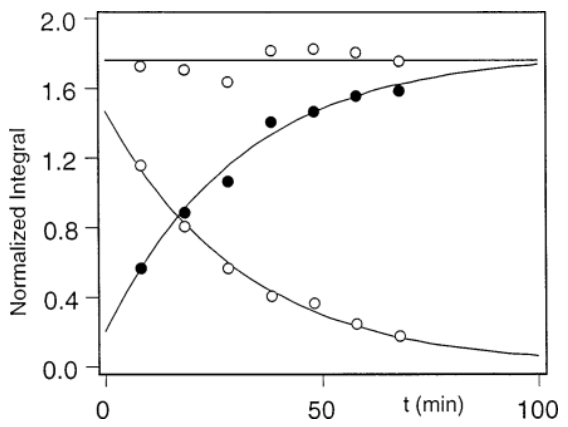

Fig. 2. Concentrations of complexes $\mathbf{3}$ and $\mathbf{4}$ from the reaction between 2 and $\mathrm{HBF}_{4}$ (1 equiv.) in $\mathrm{MeCN}$ at r.t., as obtained from the integration of the ${ }^{1} \mathrm{H}$ NMR hydride signals, a function of time. White circles: 3; black circles: 4; grey circles: total. The lines correspond to the leastsquares fittings of the data to the pertinent integrated first-order rate laws.

\subsubsection{Protonation of compound 2}

As for the $\mathrm{Cp}^{*}$ analog, the protonation of 2 by $\mathrm{HBF}_{4}$ in $\mathrm{Et}_{2} \mathrm{O}$ immediately affords analytically and spectroscopically pure $\left[\mathrm{Cp}^{\mathrm{Et}} \mathrm{MoH}_{4}(\mathrm{dppe})\right]\left[\mathrm{BF}_{4}\right](\mathbf{3})$ as a pale brown solid in good yields. Once again, the spectroscopic properties of this compound parallel those of the $\mathrm{Cp}^{*}$ analog. However, complex 3 is more inert in $\mathrm{MeCN}$ relative to the $\mathrm{Cp}^{*}$ analog. The protonation of Cp* $\mathrm{MoH}_{3}\left(\right.$ dppe) with 1 equiv. of $\mathrm{HBF}_{4}$ in $\mathrm{MeCN}$ was shown to lead directly to $\left[\mathrm{Cp}^{*} \mathrm{MoH}_{2}(\mathrm{MeCN})(\mathrm{dppe})\right]^{+}$ with gas evolution, without the observation of the tetrahydrido intermediate. The protonation of 2 under the same conditions, on the other hand, leads to the formation of the tetrahydrido derivative $\mathbf{3}$ and to its subsequent slow convertion $\left(t_{1 / 2}=22 \mathrm{~min}\right.$ at r.t.) to the dihydrido compound $\left[\mathrm{Cp}^{\mathrm{Et}} \mathrm{MoH}_{2}(\mathrm{MeCN})(\mathrm{dppe})\right]\left[\mathrm{BF}_{4}\right]$ (4), as shown by careful NMR monitoring of a reaction carried out in $\mathrm{CD}_{3} \mathrm{CN}$ (see Fig. 1). The shape of the hydride resonance of compound $\mathbf{4}$, as well as the chemical shift and the $J_{\mathrm{HP}}$, is identical to that of the corresponding $\mathrm{Cp}^{*}$ compound. The previously reported variable temperature NMR studies on the $\mathrm{Cp}^{*}$ system show that this is the result of the freezing out of an exchange between inequivalent hydride sites. Fig. 2 shows the normalized integral (1/4 of the hydride signal for 3 and $1 / 2$ of the hydride signal for 4 ) as a function of time. Fitting the data to the integrated first-order rate laws (1) and (2), respectively, provides the same firstorder rate constant within experimental error (3.2(1) $\times 10^{-2}$ and 3.2(8) $\times 10^{-2} \mathrm{~min}^{-1}$, respectively). The sum of the concentrations of $\mathbf{3}$ and $\mathbf{4}$ is approxi- mately constant and its least-squares value $(y=1.76(2)$ in the normalized integral units of Fig. 2) corresponds within experimental error to the optimized asymptotefor the concentration of $4[y(4)=1.80(14)]$. Extrapola-tion to zero time yields a non-zero value for the concen- tration of $\mathbf{4}\left[y_{0}(\mathbf{4})\right.$ $=0.20(11)]$ and a concentration of $\mathbf{3}\left[y_{0}(\mathbf{3})=1.47(5)\right]$, which is significantly lower (difference greater than $5 \mathrm{~s}$ units) than the optimized total. The sum of these two numbers $\left[y_{0}(\mathbf{3})+y_{0}(\mathbf{4})=1.67(12)\right]$, however, is within one standard deviation of the optimized total.

$$
y(3)=y_{0}(3) \mathrm{e}^{-k t} \quad \text { (1) } \quad y(\mathbf{4})=y \quad(\mathbf{4})-y_{0}(\mathbf{4}) \mathrm{e}^{-k t}
$$

In a separate experiment, this solution was treated with $\mathrm{NEt}_{3}$ before the complete conversion of $\mathbf{3}$ to $\mathbf{4}$, causing the resonances of $\mathbf{3}$ to disappear and to be replaced by those of $\mathbf{2}$, demonstrating the reversibilityof the proton transfer process. The resonances of $\mathbf{4}$, on the other hand, are not affected; thus, the latter complex is not sufficiently acidic to be deprotonated by $\mathrm{NEt}_{3}$ (see Scheme 2). The difference in reactivity be- tween the $\mathrm{Cp}^{*}$ and the $\mathrm{Cp}^{\mathrm{Et}}$ systems is also shown by other observations. The protonation of the $\mathrm{Cp}^{*}$ deriva- tive, even when the strictly stoichiometric amount of $\mathrm{HBF}_{4}$ was employed, 


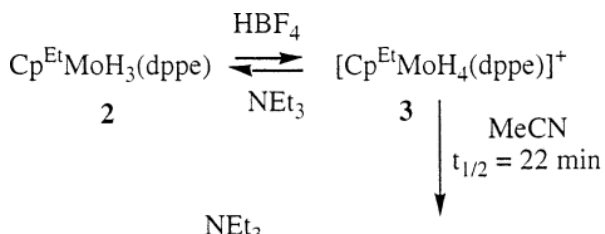

$$
\begin{aligned}
& \text { N.R. } \stackrel{\mathrm{NEt}_{3}}{\longleftarrow}\left[\mathrm{Cp}^{\mathrm{Et}} \mathrm{MoH}_{2}(\mathrm{dppe})(\mathrm{MeCN})\right]^{+} \\
& 4
\end{aligned}
$$

Scheme 2 .

always gave subsequent protonation products, identified as three different, slowly inter- converting isomers of the monohydride complex $\left[\mathrm{Cp} * \mathrm{MoH}(\mathrm{MeCN})_{2}(\text { dppe })\right]^{2+}$ [10]. The only possible way to isolate pure $\left[\mathrm{Cp}^{*} \mathrm{MoH}_{2}(\mathrm{MeCN})(\mathrm{dppe})\right]\left[\mathrm{BF}_{4}\right]$ was to dissolve the isolated (from the protonation in $\mathrm{Et}_{2} \mathrm{O}$ ) tetrahydrido derivative in $\mathrm{MeCN}$. For the $\mathrm{C}_{5} \mathrm{Et}_{5}$ system, on the other hand, the direct protonation of 2 in $\mathrm{CD}_{3} \mathrm{CN}$ with 1 equiv. of $\mathrm{HBF}_{4}$ leads to the selective formation of 4 . By carrying out the protonation on a larger scale in regular acetonitrile, the dihydrido complex $\mathbf{4}$ was isolated as an analytically pure product as a tetrafluoroborate salt.

Further protonation of complex 4 with 1 additional equiv. of $\mathrm{HBF}_{4}$ in $\mathrm{MeCN}$ shows again a chemical behavior identical to but slower rates than the previously investigated $\mathrm{Cp}^{*}$ system. For the $\mathrm{Cp}^{*}$ system, protonation of $\left[\mathrm{Cp}^{*} \mathrm{MoH}_{2}\right.$ (dppe)(MeCN) ${ }^{+}$resulted in the immediate disappearance of the starting material and the formation of the three isomeric forms of $[\mathrm{Cp} * \mathrm{MoH}(\mathrm{dppe})$ $\left.(\mathrm{MeCN})_{2}\right]^{2+}[10]$. The $\mathrm{Cp}^{\mathrm{Et}}$ system affords the same three products $\left(5,6\right.$ and 7), whose hydride ${ }^{1} \mathrm{H}$ and ${ }^{31} \mathrm{P}$ NMR resonances parallel those of the corresponding $\mathrm{Cp}^{*}$ systems (see Fig. 3). However, NMR monitoring shows that the starting material is only slowly converted into these products, the complete disappearance requiring over $1 / 2 \mathrm{~h}$ at r.t. The nature of the final products does not change when the protonation is carried out in THF, followed by drying and redissolution in $\mathrm{CD}_{3} \mathrm{CN}$. Treatment of the final solution with $\mathrm{NEt}_{3}$ results in the disappearance of $\mathbf{6}$ and $\mathbf{7}^{2}$, while the resonances of $\mathbf{5}$ remain unaltered. Complex $\mathbf{5}$ has also been isolated as an analytically pure $\mathrm{BF}_{4}$ salt by selective crystallization from the solution containing 5, 6 and 7.

The direct protonation of $\mathbf{2}$ in $\mathrm{MeCN}$ with 2 equiv. of $\mathrm{HBF}_{4}$ affords an unexpected result. For the Cp* system [10], as stated above, the tetrahydrido derivative was not observed (even when only 1 equiv. of acid wasused), leading directly to the products of double protonation

\footnotetext{
${ }^{2}$ The product(s) of this deprotonation process could not be isolated or characterized by NMR in solution and their identification was not further pursued.
}

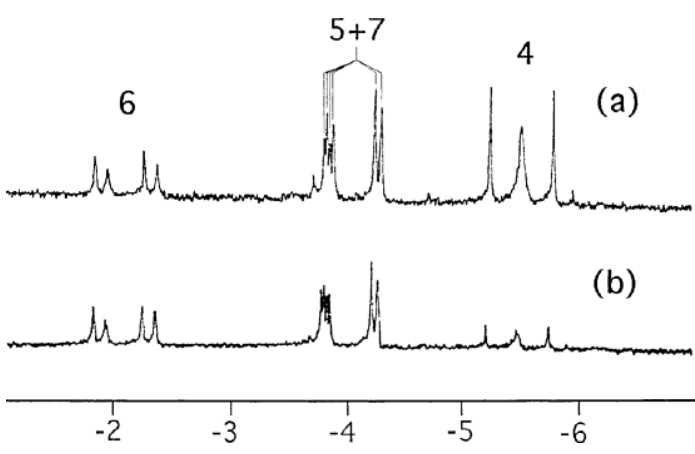

Fig. 3. Representative ${ }^{1} \mathrm{H}$ NMR spectra in the hydride region of the reaction between $\left[\mathrm{Cp}^{\mathrm{Et}} \mathrm{MoH}_{2}(\mathrm{dppe})(\mathrm{MeCN})\right]^{+}$and 1 equiv. of $\mathrm{HBF}_{4}$ in $\mathrm{CD}_{3} \mathrm{CN}$ at r.t. (a) $t=2 \mathrm{~min}$. (b) $t=25 \mathrm{~min}$.

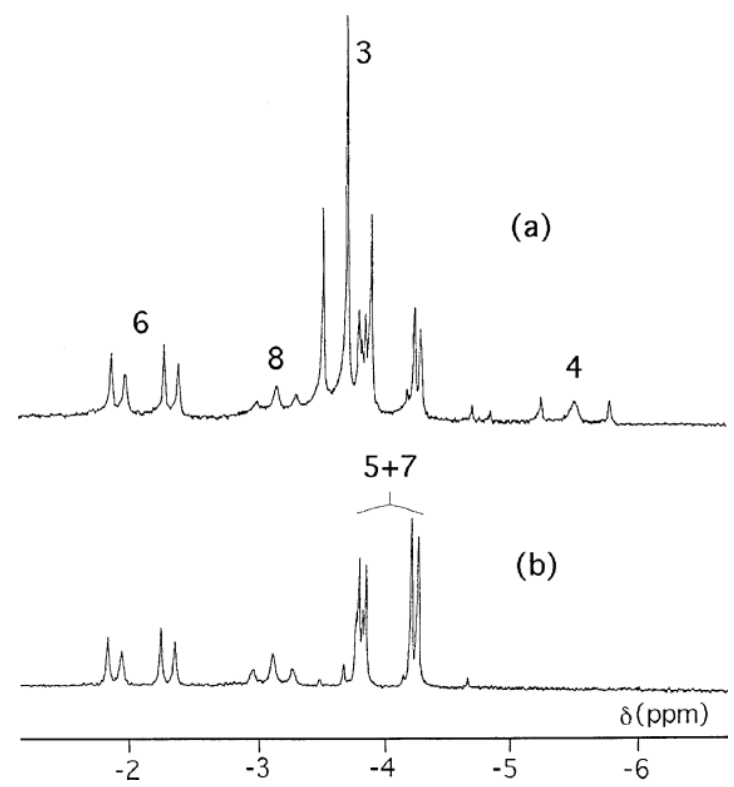

Fig. 4. Representative ${ }^{1} \mathrm{H}$ NMR spectra in the hydride region of the reaction between $\mathrm{Cp}^{\mathrm{Et}} \mathrm{MoH}_{3}$ (dppe) and 2 equiv. of $\mathrm{HBF}_{4}$ in $\mathrm{CD}_{3} \mathrm{CN}$ at r.t. (a) $t=20 \mathrm{~min}$. (b) $t=1 \mathrm{~h}$.

and double $\mathrm{H}_{2}$ elimination. For the $\mathrm{Cp}^{\mathrm{Et}}$ system, on the other hand, six distinct products were formed initially, as shown by a ${ }^{1} \mathrm{H}$ NMR monitoring in the hydride region of the reaction carried out in $\mathrm{CD}_{3} \mathrm{CN}$ (see Fig. 4). These are the tetrahydrido derivative $\mathbf{3}$, the dihydrido derivative $\mathbf{4}$, the three different forms of $\left[\mathrm{Cp}^{\mathrm{E}} \mathrm{MoH}\left(\mathrm{CD}_{3} \mathrm{CN}\right)_{2}(\mathrm{dppe})\right]^{2+}, \mathbf{5 ,} \mathbf{6}$ and $\mathbf{7}$, and a new compound characterized by a broad, low intensity ${ }^{1} \mathrm{H}$ NMR triplet resonance at $\delta-3.11\left(J_{\mathrm{HP}}=31.2\right.$ $\mathrm{Hz}$ ) and by a single ${ }^{31} \mathrm{P}$ NMR resonance at $\delta 59.51$. We shall present compelling evidence below that this new compound corresponds to the 'classical' trihydride species $\left[\mathrm{Cp}^{\mathrm{Et}} \mathrm{MoH}_{3}\left(\mathrm{CD}_{3} \mathrm{CN}\right)(\mathrm{dppe})\right]^{2+}(\mathbf{8})$.

The time evolution of the ${ }^{1} \mathrm{H}$ NMR spectrum in this double-protonation experiment is shown in Fig. 4. The persistence of 3 in the presence of excess $\mathrm{H}^{+}$(Fig. 4(a)) indicates that its further protonation is thermodynamically unfavored and/or kinetically slow. The same can initially, as shown by a ${ }^{1} \mathrm{H}$ NMR monitoring in 
$\left[\mathrm{Cp}^{\mathrm{Et}} \mathrm{MoH}_{2}(\mathrm{dppe})(\mathrm{MeCN})\right]^{+} \underset{\mathrm{NEt}_{3}}{\stackrel{\mathrm{HBF}_{4}}{\underset{\leftarrow}{\rightleftarrows}}}\left[\mathrm{Cp}^{\mathrm{Et}} \mathrm{MoH}_{3}(\mathrm{dppe})(\mathrm{MeCN})\right]^{2+}$

Scheme 3 .

be said (as shown also by the experiment in Fig. 3) about the protonation of the dihydride complex 4 . The resonances of $\mathbf{3}$ and $\mathbf{4}$ decrease slowly, disappearing after approximately $1 \mathrm{~h}$, while the resonances of $\mathbf{5}, \mathbf{6}$, and $\mathbf{7}$ increase. However, the small but noticeable resonance of the new compound $\mathbf{8}$ is very persistent. It eventually disappears only after several hours, leaving only compounds 5, $\mathbf{6}$ and $\mathbf{7}$ as the final products. Unfortunately, ${ }^{31} \mathrm{P}$ NMR experiments with selective proton decoupling could not provide direct evidence of the number of hydride ligands in complex 8. However, after the complete disappearance of complexes $\mathbf{3}$ and $\mathbf{4}$ (Fig. 4(b)), the addition of excess $\mathrm{NEt}_{3}$ caused the resonances of the new compound $\mathbf{8}$ to disappear and those of $\mathbf{4}$ to reappear, from which the assignment of $\mathbf{8}$ as a trihydride compound directly follows. Further arguments in favor of the formulation of $\mathbf{8}$ as a trihydride species will be presented in Section 4. In a separate experiment, $\mathrm{D}_{2} \mathrm{O}$ was added when all com- pounds 3-8 were still present, as in Fig. 4(a). This caused the disappearance of the resonance of $\mathbf{8}$, whileall other resonances remained unaffected. It is to beunderlined that $\mathbf{8}$ forms only by direct double protona- tion of $\mathbf{2}$ and not by protonation of 4 (Scheme 3, see Section 4).

\subsubsection{Protonation of compound $\mathbf{2}-\mathbf{d}^{3}$}

The addition of 1 equiv. of $\mathrm{HBF}_{4}$ to compound $\mathbf{2}-\boldsymbol{d}^{\mathbf{3}}$ provides results consistent with those of the protonation study of 2 . The immediate formation of $\left[\mathrm{Cp}^{\mathrm{Et}} \mathrm{MoD}_{n} \mathrm{H}_{4-n}(\mathrm{dppe})\right]^{+}(\mathrm{n} \leq 3)$ species $\left(\mathbf{3}-\boldsymbol{d}^{\leq 3}\right)$ is shown by the appearance of a triplet hydride resonance, whose chemical shift and $J_{\mathrm{HP}}$ are identical with those of complex 2 within experimental error. Thus, the H/D isotopic substitution at the hydride position does not affect the chemical shift for this particular hydride complex. The absence of an isotopic shift does not conclusively disprove the presence of dihydrogen ligands $s^{3}$ [19], but is rather more in agreement with a classical polyhydride formulation. The absence of any noticeable H/D couplings is also in favor of a classical structure. One rather surprising observation is the immediate appearance of $\mathrm{H}_{2}$, as well as $\mathrm{HD}$, in the ${ }^{1} \mathrm{H}$ NMR spectrum (see Fig. 5(a)). This observation is a clear indication of reversibility in the protonation process of 2 to afford 3 (see Section 4). The hydride resonance of 3-d $\boldsymbol{d}^{\mathbf{3}}$ subsequently decreases $\left(t_{1 / 2} \mathrm{~B} 10 \mathrm{~min}\right)$, while the broadened triplet resonances of $\mathbf{4}-\boldsymbol{d}^{\leq \mathbf{1}}$ replaces it. As for system 3, different isotopomers could not be distinguished by ${ }^{1} \mathrm{H}$ NMR for system 4 .

Once the conversion of 3-d $\boldsymbol{d}^{\mathbf{3}}$ to $\mathbf{4}-\boldsymbol{d}^{\mathbf{1}}$ was complete (approximately $1 / 2 \mathrm{~h}$ ), the addition of 1 additional equiv. of $\mathrm{HBF}_{4}$ revealed the slow conversion of $\mathbf{4 - d ^ { \leq \mathbf { 1 } }}$ to $\mathbf{5 , 6}$ and 7. The intensities of the hydride resonances for the

\footnotetext{
${ }^{3}$ For instance, no significant isotopic shift is observed for the nonclassical complexes $\left[\mathrm{Cp} * \mathrm{MH}_{4}\left(\mathrm{H}_{2}\right)\left(\mathrm{PMe}_{3}\right)\right]^{+}(\mathrm{M}=\mathrm{Mo}, \mathrm{W})$, see Ref. [19].
}

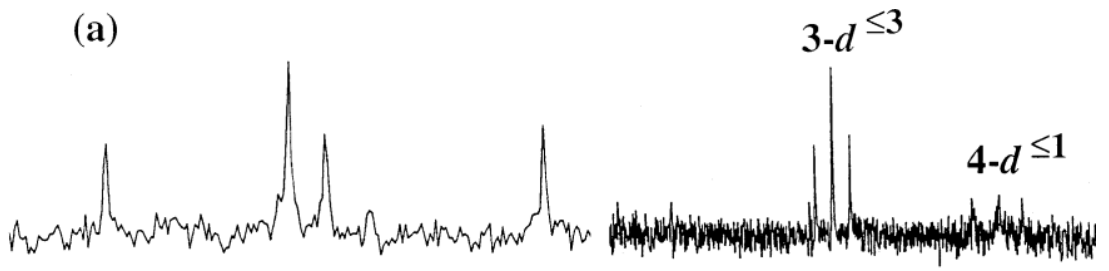

(b)

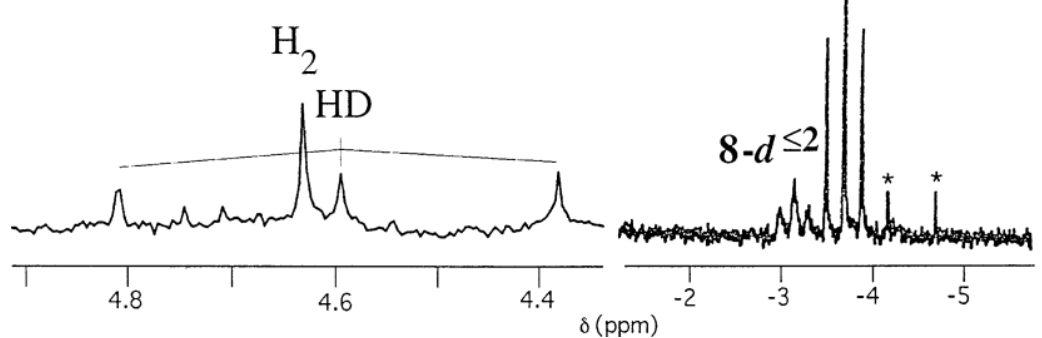

Fig. 5. ${ }^{1} \mathrm{H}$ NMR spectrum in the hydride region of the solution obtained by adding $\mathrm{HBF}_{4}$ to $\mathrm{Cp}^{\mathrm{Et}} \mathrm{MoD}_{3}(\mathrm{dppe})$ in $\mathrm{CD}_{3} \mathrm{CN}$ at $\mathrm{r} . \mathrm{t}$. (a) $\mathrm{HBF}_{4} / \mathrm{Cp}^{\mathrm{Et}} \mathrm{MoD}_{3}(\mathrm{dppe})=1 ; t=2-7 \mathrm{~min}$. (b) $\mathrm{HBF}_{4} / \mathrm{Cp}^{\mathrm{Et}} \mathrm{MoD}_{3}(\mathrm{dppe})=2 ; t=10-15 \mathrm{~min}$. The starred peaks correspond to unknown impurities. 
products are rather small, because only part of $\mathbf{4 - d ^ { \leq 1 }}$ is converted to the NMR active hydride signals by protonation at the $\mathrm{D}$ position, while protonation atthe $\mathrm{H}$ position affords deuteride products having no ${ }^{1} \mathrm{H}$ NMR-visible hydride resonances.

The direct addition of 2 equiv. of $\mathrm{HBF}_{4}$ to compound $\mathbf{2}-\boldsymbol{d}^{\mathbf{3}}$ produced the same species obtained from the analogous reaction of compound $\mathbf{2}$, as shown by the ${ }^{31} \mathrm{P}$ NMR spectrum. However, the ${ }^{1} \mathrm{H}$ NMR spectrum in the hydride region (Fig. 5(b)) shows only peaks corresponding to compounds 3-d $\boldsymbol{d}^{\leq \mathbf{3}}$ and $\left[\mathrm{Cp}^{\mathrm{Et}} \mathrm{Mo}-\right.$ $\left.\mathrm{D}_{n} \mathrm{H}_{3-n}(\mathrm{dppe})\left(\mathrm{CD}_{3} \mathrm{CN}\right)\right]^{2+} \quad\left(\mathbf{8}-\boldsymbol{d}^{\leq \mathbf{2}}\right)$. The hy- dride resonance of $\mathbf{8 - \boldsymbol { d } ^ { \leq 2 }}$ is not significantly shifted from that of 8 and does not show indications of $\mathrm{H}-\mathrm{D}$ coupling, again suggesting a classical structure. Since the corresponding experiment with the trihydride precursor 2 also leads to the observation of 4, 5, 6 and 7 under the same conditions, it must be concluded that all these products are either fully deuterated or they form more slowly when obtained from $2-d^{3}$. The ${ }^{1} \mathrm{H}$ NMR spectrum also shows the formation of a mixture of $\mathrm{H}_{2}$ and $\mathrm{HD}$ (Fig. 5(b)). The initial $\mathrm{H}_{2}$ : HD ratio is greater when using 2 equiv. of $\mathrm{HBF}_{4}$ (0.70, Fig. 5(b)) than when using 1 equiv. (0.20, Fig. 5(a)). The spectra were recorded with long relaxation delays (90 s) to ensure full magnetization recovery for HD.

The evolution of the ${ }^{1} \mathrm{H}$ NMR spectrum for the 2$d^{3} / 2 \mathrm{H}^{+}$reaction parallels that of the $2 / 2 \mathrm{H}^{+}$reaction with regards to the disappearance of species $\mathbf{3}$ and $\mathbf{8}$ (both became unobservable after approximately $6 \mathrm{~h}$ from the $\mathrm{HBF}_{4}$ addition). However, signals corresponding to species 5, 6 and 7 started to appear after approximately 30 min, while a signal attributable to $4-\boldsymbol{d}^{\leq 1}$ was never observed for this experiment.

\subsection{Chemical oxidation of $\mathrm{Cp}^{\mathrm{Et}} \mathrm{MoH}_{3}($ dppe $)$ in acetonitrile}

As mentioned above, compound $\mathbf{2}$ is oxidized at about the same potential as its $\mathrm{Cp}^{*}$ analogue. The oxidized product $\mathbf{2}^{\mathbf{+}^{\prime}}$, however, decomposes much more slowly as shown by the reversibility of the cyclic voltammetric wave down to $10 \mathrm{mV} \mathrm{s}^{-1}$, even in $\mathrm{MeCN}$. Chemical oxidation by 1.5 equiv. of ferrocenium in $\mathrm{MeCN}$ allows the observation of the transient EPR spectrum of $\mathbf{2}^{\mathbf{+}^{\prime}}$, while the one-electron oxidation product for the $\mathrm{Cp}^{*}$ analog could only be observed in THF and $\mathrm{CH}_{2} \mathrm{Cl}_{2}$. An EPR monitoring of the $\mathbf{2}^{\boldsymbol{+}^{\prime}}$ solution shows that this signal is slowly replaced by a triplet $\left(g=1.984, a_{\mathrm{P}}=26.9 \mathrm{G}\right.$, $a_{\mathrm{Mo}}=47.6 \mathrm{G}$ ) within $1 \mathrm{~h}$, whereas the $\mathrm{Cp}^{*}$ analog gave an EPR silent solution. The magnitude of the hyperfine constant is diagnosticfor phosphorus coupling. This and the absence of any additional coupling attributable to $\mathrm{H}$ nuclei make us suppose that the spectrum corresponds to a diphosphine, non-hydridic complex, such as $\left[\mathrm{Cp}^{\mathrm{Et}}\right.$ -
Mo(dppe) $\left.(\mathrm{MeCN})_{2}\right]^{2+}$, whose formation can be rationalized on the basis of our working mechanistic hypotheses (see Section 4). We have not, however, further pursued the identification of this material. The NMR spectrum ofthe final solution reveals the presence of the same types of products that are also obtained by oxidation of $\mathrm{Cp}^{*} \mathrm{MoH}_{3}$ (dppe) in $\mathrm{MeCN}$, namely complexes 4 and 5 in an approximately 1:1 ratio, plus another non-hydridic product, which remains unidentified. The NMR experiment also shows that complex $\mathbf{3}$ is initially present during this experiment, but later disappears transforming into $\mathbf{4}$, as already established by the protonation experiment. It is to be remarked that at no time during this experiment is there any evidence for the accumulation of complex $\mathbf{8}$.

An analogous experiment carried out with 2 equiv. of ferrocenium reveals that only $\mathbf{3}$ (major) and $\mathbf{5}$ (minor) are obtained initially. No compound $\mathbf{4}$ is present during the initial moments of the reaction, but it forms later as the resonances of $\mathbf{3}$ disappears. The unassigned non-hydridic product, on the other hand, is absent at all times, whereas the strong EPR signal attributed to $\left[\mathrm{Cp}^{\mathrm{Et}} \mathrm{Mo}(\mathrm{dppe})(\mathrm{MeCN})_{2}\right]^{2+\bullet}$ is present.

\section{Discussion}

\subsection{Mechanism of the protonation process}

The results of the protonation studies on compounds $\mathbf{2}$ and $\mathbf{2}-\boldsymbol{d}^{\mathbf{3}}$ are rationalized by the mechanistic Scheme 4 , which follows and expands the previously reported one from the protonation studies of the $\mathrm{Cp}^{*}$ analog, $\mathrm{Cp} * \mathrm{MoH}_{3}$ (dppe) [10]. The results of the protonation experiment of 2 with 1 equiv. of $\mathrm{HBF}_{4}$ (Fig. 2), notably the proportion of the products $\mathbf{3}$ and $\mathbf{4}$ at zero time, would tend to suggest that protonation of $\mathbf{2}$ can occurby two competitive pathways, formally correspondingto direct protonation at the metal (to afford $\mathbf{3}$, major pathway) and protonation at the hydride position to afford a dihydrogen ligand, which is immediately re- placed by acetonitrile to afford 4 (minor pathway). It cannot be excluded, however, that the protonation al- ways occurs kinetically at the hydride position to afford a nonclassical intermediate $\mathbf{I}$, as suggested previously for other protonation reactions [20-22]. If this is the case, the collapse of the nonclassical intermediate to the classical product must be much faster than the replacement of the $\mathrm{H}_{2}$ ligand by acetonitrile. One way or the other, the results of this experiment indicate that proto- nation of compound $\mathbf{2}$ occurs, at least in part, at the hydride site.

The results of the protonation of $\mathbf{2}-\boldsymbol{d}^{\mathbf{3}}$, notably the immediate formation of $\mathrm{H}_{2}$, are a clear indication of reversibility for the protonation process. An irreversibility in the formation of both $\mathbf{3}-\boldsymbol{d}^{\mathbf{3}}$ and $\mathbf{I}-\boldsymbol{d}^{\mathbf{3}}$ could 


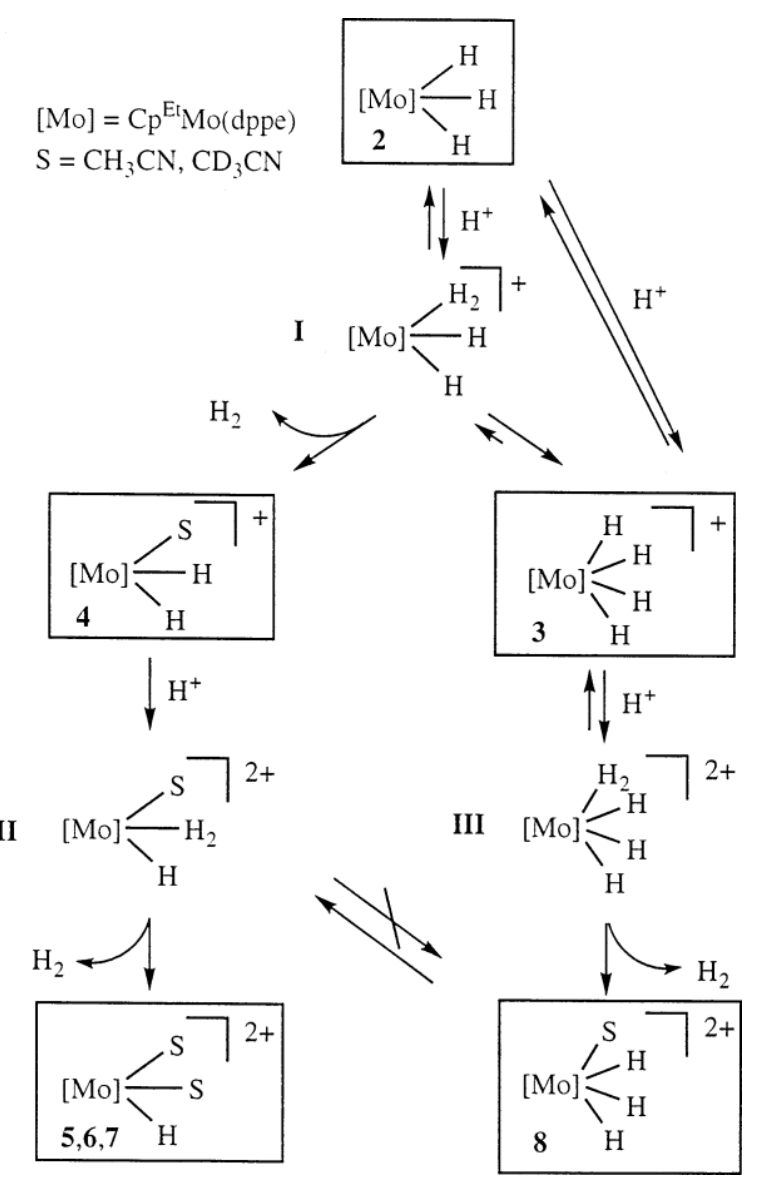

Scheme 4.

only lead to the formation of HD. On the other hand, reversibility could occur either for the hydride protonation, or for the metal protonation (if this occurs), or for both. Jia and Morris have studied protonation/deprotonation reactions on both classical and non-classical polyhydride complexes that are in equilibrium with each other and have established that the non-classical form has a greater kinetic acidity [22,23]. A reversible protonation process at the hydride position seems therefore more likely. The formation of a mixture of $\mathrm{H}_{2}$ and HD can thus be rationalized as shown in Scheme 5 . A fast dynamic exchange process between classical and non-classical sites could equilibrate the isomers shown and lead to the formation of a mixture of HD, $\mathrm{D}_{2}, \mathbf{4 - d ^ { 2 }}$ and 4- $\boldsymbol{d}^{\mathbf{1}}$ from $\mathbf{I}-\boldsymbol{d}^{\mathbf{3}}$, and to a mixture of $\mathrm{H}_{2}, \mathrm{HD}, \mathrm{D}_{2}$,

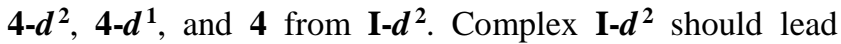
to the preferential elimination of $\mathrm{H}_{2}$ if the $\mathrm{H}$ atoms have a preference for the non-classical sites, as indicated by isotopic perturbation of resonance (IPR) experiments on another polyhydride complex [24]. The results also show that the deprotonation from $\mathbf{I}-\boldsymbol{d}^{\mathbf{3}}$ must be faster than the replacement of $\mathrm{HD}$ by $\mathrm{MeCN}$ or than the collapse to $\mathbf{3}-\boldsymbol{d}^{\mathbf{3}}$. Therefore, further reversible proton transfer processes will probably occur from intermediate $\mathbf{I}-\boldsymbol{d}^{\mathbf{2}}$ to also afford $\mathbf{I}-\boldsymbol{d}^{\mathbf{1}}$ and $\mathbf{I}$. In agree- ment with the proposed scheme, the initial $\mathrm{H}_{2}: \mathrm{HD}$ ratio increases from 0.20 to 0.70 when the $\mathrm{H}^{+} / \mathbf{2}-\mathbf{d}^{\mathbf{3}}$ ratio is increased from 1 to 2 .

The protonations of $\mathbf{3}$ and $\mathbf{4}$ are rather slow processes, as shown in Figs. 2 and 4. A slower protonation for positively charged complexes relative to neutral species is expected on the basis of the Coulombic repulsive effect. On the other hand, the corresponding cationic $\mathrm{Cp}^{*}$ systems are protonated immediately. We attribute this difference to steric effects, since the $\mathrm{C}_{5} \mathrm{Me}_{5}$ and $\mathrm{C}_{5} \mathrm{Et}_{5}$ rings are electronically equivalent, as shown by the similarity of the NMR and redox proper ties. All

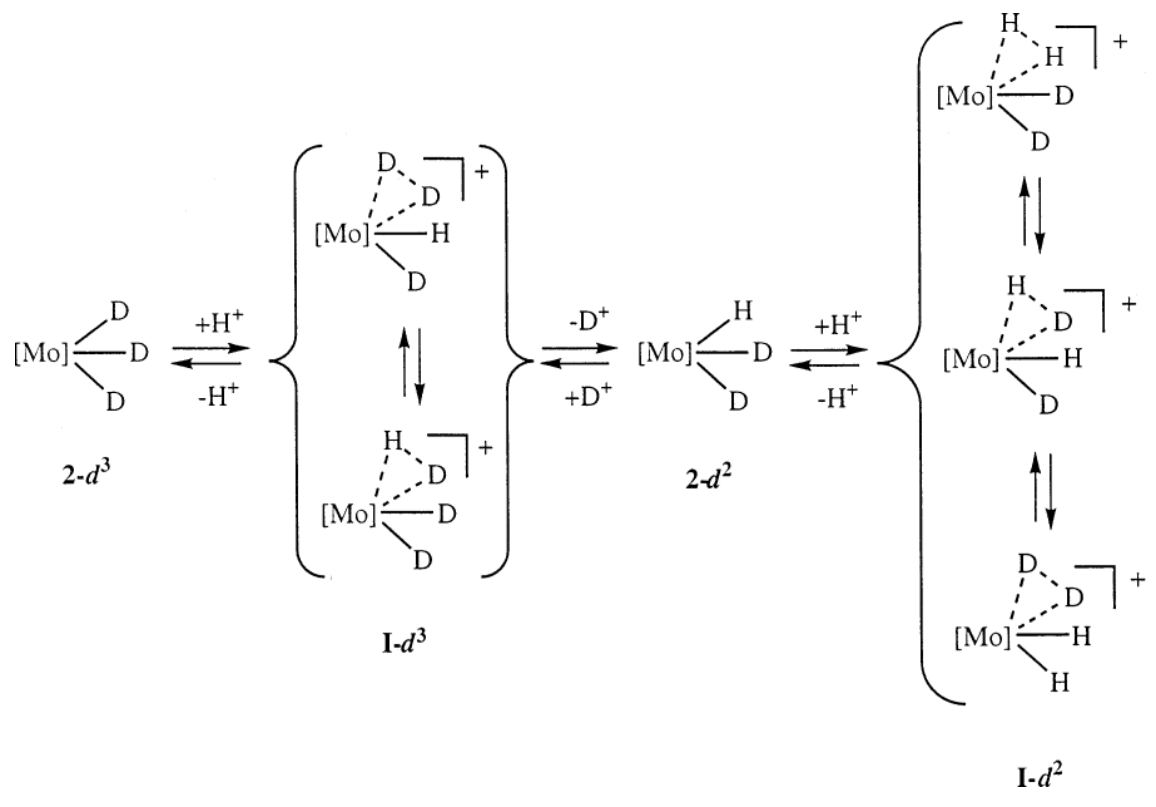

Scheme 5 . 


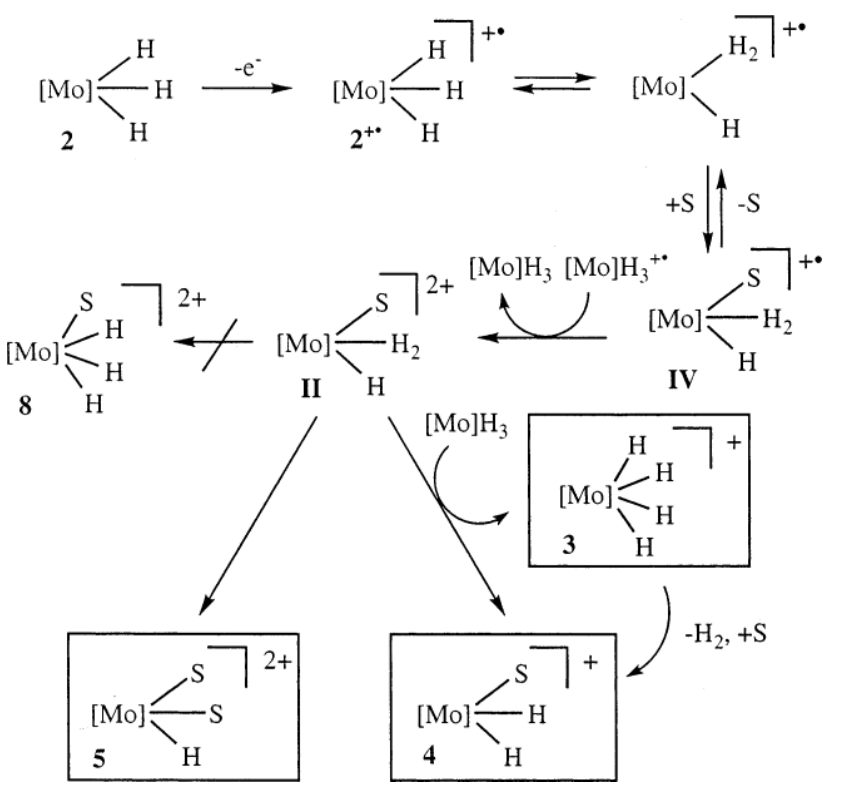

Scheme 6.

available crystal structures of $\mathrm{C}_{5} \mathrm{Et}_{5}$ derivatives reveal the same conformation for the ring, with all five ethyl substituents bent toward the same side of the ring away from the metal [25-28]. This conformation does not impose any additional steric encumberance to anattack of the other ligands by external reagents. However, it is likely that the ethyl groups are freely rotating around the ring $-\mathrm{C}_{2} \mathrm{H}_{5}$ axes in solution, yielding a much greater effective cone angle for the $\mathrm{C}_{5} \mathrm{Et}_{5}$ ligand.

The protonation of $\mathbf{4}$ yields directly the monohydride products, without any evidence for the intermediacy of the trihydride derivative 8 . The most reasonable explanation of this result is to invoke the protonation of a hydride ligand to afford intermediate II (Scheme 4), which immediately expels the $\mathrm{H}_{2}$ ligand rather than collapse to the classical tautomer. Thus, no direct protonation at the metal occurs for system 4, suggesting that the $\mathrm{Mo} \mathrm{H}$ bond presumably retains a $\mathrm{Mo}-\mathrm{H}^{\delta^{-}}$bond polarity in agreement with the inability of $\mathrm{NEt}_{3}$ to deprotonate the complex. According to this scheme, therefore, the behavior of intermediates I and II is completely different, the first one preferring to rear-range to the classical tautomer over the $\mathrm{H}_{2} / \mathrm{MeCN}$ exchange by at least a 4:1 margin, whereas the second one leads exclusively to substitution of the $\mathrm{H}_{2}$ ligand. This difference can be rationalized on the basis of the differences between the two substrates. Both I and II are formally $\mathrm{Mo}(\mathrm{IV})$ systems but the charge increase on going from the former to the latter (caused by the formal replacement of $\mathrm{H}^{-}$by acetonitrile) renders the metal a weaker $\mathrm{p}$ base, weakening the $\mathrm{Mo}_{2}$ interac- tion in favor of substitution and in disfavor of oxidative rearrangement.

The trihydride complex $\mathbf{8}$ is only observed by direct double protonation of $\mathbf{2}$ (or $\mathbf{8}-\boldsymbol{d}^{\leq \mathbf{2}}$ from double proto- nation of $\mathbf{2}-\boldsymbol{d}^{\mathbf{3}}$ ). This signifies that its formation requiresa direct protonation of $\mathbf{3}$ without the intermediacy of $\mathbf{4}$. As suggested above for the protonation of $\mathbf{2}$ and $\mathbf{4}$, we propose that the protonation of $\mathbf{3}$ occurs at a hydride ligand to afford intermediate III, as shown in Scheme 4. As a matter of fact, there is no choice in this case because there are no lone pairs remaining on a metalbased orbital. Thus, intermediate III is unable to rearrange to a classical tautomer and can only undergo substitution of the $\mathrm{H}_{2}$ ligand with an acetonitrile molecule, to afford $\mathbf{8}$. The slow rate of disappearance of $\mathbf{3}$ suggests that its protonation to III is probably easily reversed, allowing the formation of mixtures of III- $\boldsymbol{d}^{\mathbf{3}}$, III- $\boldsymbol{d}^{2}$, etc. from $\mathbf{3 - \boldsymbol { d } ^ { \leq \mathbf { 3 } }}$ by deprotonation/protonation processes by analogy with the reversible protonation of $\mathbf{2}$ in Scheme 5. Once formed, complex $\mathbf{8}$ is quite inert showing that, in spite of the high metal charge, the barrier to the reductive elimination process is relatively high.

Compound $\mathbf{8}$, however, shows a relatively high acidity; it is deprotonated by $\mathrm{NEt}_{3}$ and by $\mathrm{D}_{2} \mathrm{O}$, while compound 3 is deprotonated only by $\mathrm{NEt}_{3}$, its ${ }^{1} \mathrm{H}$ NMR hydride resonance remaining unaffected in thepresence of $\mathrm{D}_{2} \mathrm{O}$. Since $\mathbf{3}$ and $\mathbf{8}$ are formally related by the replacement of a $\mathrm{H}^{-}$ligand with a $\mathrm{MeCN}$ ligand, the above comparison is in agreement with a stronger donating power for $\mathrm{H}^{-}$, which is also independently indicated by the trend of oxidation potentials $\left(E_{1 / 2}: \mathbf{2}<\right.$ $4<5$ ).

\subsubsection{Mechanism of the oxidation process}

The results of the chemical oxidation in $\mathrm{MeCN}$ can be accommodated by the mechanism illustrated in Scheme 6, which follows and expands the previously reported one from the oxidation studies of the $\mathrm{Cp}^{*}$ analogue [12]. Compound $\mathbf{2}$ is oxidized by ferrocenium to afford the radical species $\mathbf{2}^{\boldsymbol{+}^{\prime}}$ in the classical form. The decomposition, however, proceeds via the nonclassical form whose relative energy becomes kinetically accessible as a result of the oxidation. This conclusion was attained from a comparative stability and decomposition mechanism study for the $\mathrm{Cp}^{*} \mathrm{Mo}$ and $\mathrm{W}$ systems [12]. Acetonitrile then accesses the open coordination site to afford equilibrium amounts of a 19-electron species (intermediate IV in Scheme 6), which can be oxidized by the residual 17 -electron $2^{+}$in a precedented [12,29-31] ligand-induced disproportionation reaction. Electrochemical and kinetics studies on the analogous $\mathrm{Cp}^{*}$ system have led to the above conclusions [12].

No assumption on the intimate structure of the oxidation product, which results from the disproportionation step, namely the doubly cationic trihydrido species, was made in the previously reported $\mathrm{Cp}^{*}$ study. However, the classical form of this compound corresponds to $\mathbf{8}$, which is shown by the protonation studies to be a 
kinetically inert species. Since this is not observed as a product of the oxidation reaction with either 1 or 2 equiv. of ferrocenium, we must assume that the disproportionation of $[2]^{+}$or the direct double oxidation of 2 leads to the nonclassical tautomer, i.e. II. This assumption is indeed logical if the 19-electron precursor IV also adopts a nonclassical structure. As shown above, intermediate II evolves to compound $\mathbf{5}$ rather than collapsing to the classical tautomer 8 (Scheme 4). The rest of the Scheme again parallels what was previously proposed for the $\mathrm{Cp}^{*}$ study. The selective formation of $\mathbf{5}$ (and not 6 or 7) parallels what has been observed for the Cp* system and the same rationalization should hold here, namely that intermediate II is obtained in a single isomeric form during the electron transfer process, while it may be obtained under different forms during the protonation process.

The EPR active species with a triplet signal at $g=$ 1.984 has been attributed to the 17-electron complex $\left[\mathrm{Cp}^{\mathrm{Et}} \mathrm{Mo}(\mathrm{dppe})(\mathrm{MeCN})\right]^{2+}$, whose formation can in principle be imagined in two different ways. The simplest one involves deprotonation of $\mathbf{5}$ by $\mathbf{2}$, followed by oxidation by residual ferrocenium (Scheme 7). However, a control experiment has shown that complex $\mathbf{5}$ is not deprotonated by complex $\mathbf{2}$. Thus, this mechanistic hypothesis must be abandoned.

A second mechanistic hypothesis involves oxidation of product $\mathbf{4}$ by excess ferrocenium to afford intermediate VI, which would lead directly to the product by reductive elimination of $\mathrm{H}_{2}$ (Scheme 8). A parallel electrochemical experiment shows the feasibility of this process, because complex 4 exhibits a reversible oxidation wave at $E_{1 / 2}=-0.06 \mathrm{~V}$. Thus, excess ferrocenium has sufficient oxidizing power to convert 4 into its oneelectron oxidation product. On the other hand, complex $\mathbf{5}$ is oxidized at a much higher potential and $\mathbf{3}$ is not oxidized before the solvent discharge. More detailed electrochemical studies of complexes $\mathbf{2}, \mathbf{4}$ and $\mathbf{5}$ are underway and will be reported separately [32].

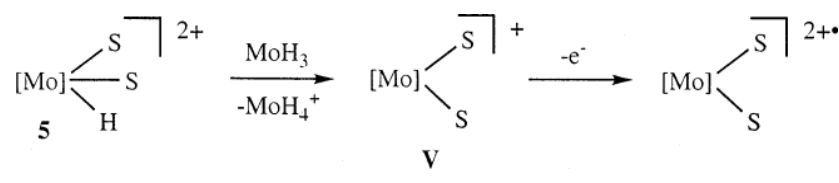

Scheme 7.

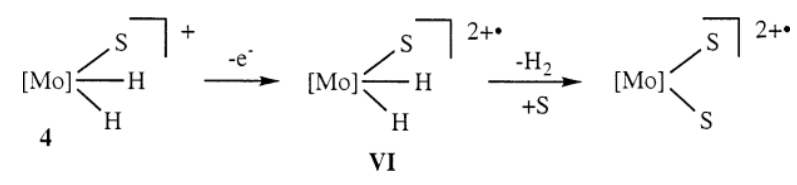

Scheme 8 .

\section{Conclusions}

Protonation and oxidation studies on the pentaethylcyclopentadienyl trihydride complex $\mathbf{2}$ show evidence for steric protection by the increased bulk of the cylopentadienyl ring in solution, resulting in slower decomposition rates for several derivatives, such as the primary oxidation product, $[2]^{\prime+}$, toward disproportionation and the conjugate acid, 3 , toward $\mathrm{H}_{2}$ reductive elimination in $\mathrm{MeCN}$. The inertness of $\mathbf{3}$ has allowed us to provide evidence of a process of further protonation with formation of the hiterto unknown classical trihydride compound $\mathbf{8}$, which formally corresponds to the product of double oxidation of $\mathbf{2}$. However, $\mathbf{8}$ cannot be accessed via the double oxidation process because the irreversible rearrangement to a non-classical structure takes place after the first oxidation step.

\section{Acknowledgements}

We are grateful to the CNRS and the MENRT for support of this work. We also thank Professor Helmut Sitzmann for a generous gift of compound

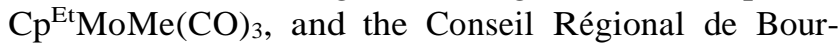
gogne and the II Plan Regional de Investigation del Principado de Asturias (Spain) for postoctoral fellowships to D.M.

\section{References}

[1] R.M. Bullock, Comm. Inorg. Chem. 12 (1991) 1.

[2] G.W. Parshall, Homogeneous Catalysis: The Applications and Chemistry of Catalysis by Soluble Transition Metal Complexes, Wiley, New York, 1980.

[3] A. Dedieu (Ed.), Transition Metal Hydrides, VCH, New York, 1992.

[4] R.H. Crabtree, J. Organomet. Chem. 577 (1998) 111.

[5] C. Bianchini, A. Meli, Acc. Chem. Res. 31 (1998) 109.

[6] T. Aviles, M.L.H. Green, A.R. Dias, C. Romão, J. Chem. Soc., Dalton Trans. (1979) 1367.

[7] M.L.H. Green, G. Parkin, J. Chem. Soc., Dalton Trans. (1987) 1611.

[8] P.D. Grebenik, M.L.H. Green, A. Izquierdo, V.S.B. Mtetwa, K. Prout, J. Chem. Soc., Dalton Trans. (1987) 9.

[9] J.C. Fettinger, B. Pleune, R. Poli, J. Am. Chem. Soc. 118 (1996) 4906.

[10] B. Pleune, R. Poli, J.C. Fettinger, Organometallics 16 (1997)1581.

[11] B. Pleune, R. Poli, J.C. Fettinger, J. Am. Chem. Soc. 120 (1998) 3257.

[12] B. Pleune, D. Morales, R. Meunier-Prest, P. Richard, E. Col- lange, J.C. Fettinger, R. Poli, J. Am. Chem. Soc. 121 (1999)2209.

[13] H.J. Lucas, E.R. Kennedy, Org. Synth. 22 (1942) 482.

[14] N.G. Connelly, W.E. Geiger, Chem. Rev. 96 (1996) 877.

[15] M. Brookhart, B. Grant, A.F. Volpe Jr., Organometallics 11 (1992) 3920. 
[16] S.T. Krueger, B.E. Owens, R. Poli, Inorg. Chem. 29 (1990) 2001.

[17] D.W. Keogh, R. Poli, in: W.A. Herrmann (Ed.), Synthetic Methods of Organometallic and Inorganic Chemistry (Herrmann/Brauer), Vol. 8, Thieme, Stuttgart, 1997, p. 99-100.

[18] R.C. Murray, L. Blum, A.H. Liu, R.R. Schrock, Organometallics 4 (1985) 953

[19] C.A. Bayse, M.B. Hall, B. Pleune, R. Poli, Organometallics 17 (1998) 4309

[20] G. Parkin, J.E. Bercaw, J. Chem. Soc., Chem. Commun. (1989) 255.

[21] M.S. Chinn, D.M. Heinekey, J. Am. Chem. Soc. 112 (1990) 5166.

[22] G. Jia, A.J. Lough, R.H. Morris, Organometallics 11 (1992) 161.

[23] G. Jia, R.H. Morris, J. Am. Chem. Soc. 113 (1991) 875.

[24] D.M. Heinekey, W.J. Oldham Jr., J. Am. Chem. Soc. 116 (1994) 3137.
[25] K.-M. Chi, J.C. Calabrese, W.M. Reiff, J.S. Miller, Organometallics 10 (1991) 688.

[26] D. Stein, H. Sitzmann, R. Boese, J. Organomet. Chem. 421 (1991) 275.

[27] D. Stein, H. Sitzmann, E. Dormann, H. Winter, J. Organomet. Chem. 412 (1991) 143.

[28] D. Morales, B. Pleune, R. Poli, P. Richard, J. Organomet. Chem. 596 (2000).

[29] G. Pilloni, G. Schiavon, G. Zotti, S. Zecchin, J. Organomet. Chem. 134 (1977) 305.

[30] K.-T. Smith, C. Rømming, M. Tilset, J. Am. Chem. Soc. 115 (1993) 8681.

[31] J.C. Fettinger, H.-B. Kraatz, R. Poli, E.A. Quadrelli, R.C. Torralba, Organometallics 17 (1998) 5767.

[32] R. Meunier-Prest, personal communication. 